\title{
Biological Monitoring of Exposure to Inorganic Lead in Pregnant Women of Meerut City (Uttar Pradesh), India
}

Sakshi Goswami, Yeshvandra Verma and Suresh Vir Singh Rana*

Department of Toxicology, Ch Charan Singh University, Meerut - 250001, Uttar Pradesh, India; sureshvs_rana@yahoo.com

\begin{abstract}
This study was conducted to monitor lead poisoning, if any, in pregnant women of Meerut City, a town of Northern India. The parameters selected included urinary concentration of lead and $\delta$-aminolevulinic acid. Further, whole body oxidative stress caused by environmental lead exposure has also been determined through urinary concentration of thiobarbituric acid Reactive Substances (TBARS). Present results show that lead concentration in pregnant women $(26-30$ years) was higher $(52 \pm 0.01 \mu \mathrm{g} / \mathrm{dL})$ than younger $(20-25$ years $)(40 \pm 0.01 \mu \mathrm{g} / \mathrm{dL})$ and older (31-40 years) $(43 \pm 0.01 \mu \mathrm{g} / \mathrm{dL})$ women. Further, highest concentration of $\delta$-aminolevulinic acid in urine $(2.60 \pm 0.55 \mathrm{mg} / \mathrm{l})$ was also recorded in the pregnant women aged between 26-30 years. Women in the age group of 20-25 years and consuming non-vegetarian diet showed comparatively higher values for TBARS $(5.56 \pm 0.6 \mu \mathrm{M})$. Higher concentration of lead in the urine samples of pregnant women than nonpregnant women is attributed to calcium stress and its increased release from bones during pregnancy. It is concluded that pregnant women of north India and their growing fetuses are more vulnerable to environmental lead poisoning.
\end{abstract}

Keywords: $\delta$-aminolevulinic acid, Lead, Oxidative Stress, Pregnant Women

\section{Introduction}

Lead is ubiquitous in the environment. Human exposure to lead may occur through air, water and food. National Referral Centre for Lead Poisoning in India (NRCLPI) suggests that air, water and food in different cities of India are contaminated with lead (NRCLPI, 2002) ${ }^{24}$. According to National Ambient Air Quality Standards, annual time weighted average concentration of lead varies from 0.50 to $1.0 \mu \mathrm{g} / \mathrm{m}^{2}$ (CPCB, 2009). Despite drinking water specifications (IS-10500-1991) prescribing lead content in water not to exceed $50 \mathrm{ppb}$, it ranges from 50-400 ppb in India. Whereas, WHO standard for lead in drinking water is less than $10 \mathrm{ppb}$ (Vikas Ecotech, 2016 $)^{44}$, ground water of Meerut and adjoining cities of north India have also been found contaminated with lead (Gaur et al., 2011 $1^{13}$, Kulshreshtha et al, 2015 ${ }^{17}$ ). Occupational exposure further adds to body burden of lead.

Several excellent reviews on toxicity of lead can be found in literature (Goyer 1996 ${ }^{14}$, Tsuchiya 1986 ${ }^{42}$, ASTDR 2007³). The body burden of lead in modern man has been found 1000 times higher than pre-historic man (Patterson et al., $1991^{28}$ ). Upon human exposure, it can be distributed to blood, soft tissues and calcified organs. In females, it can even be distributed to ovaries (Barry, 1978 7 ). It can affect female sexual maturation (Wu et al., 2003 ${ }^{46}$ ) and delay pregnancy (Sallmen et al., $\left.1995^{35}\right)$. In pregnant women, it can cause hemodilution/ anaemia. It can be mobilized from bones causing an increase in blood lead ( $\mathrm{PbB}$ ) concentrations (Rothenberg et al., 199433). Lead poisoning in pregnant women, lactating mothers and children has been reported in several countries (Zielhuis $1974^{47}$, Tong et al., 2000 ${ }^{40}$ ). Whereas, Amitai estimated prenatal lead exposure in Israel (Amitai et al., 1999²), Paoliello and De Capitani determined environmental human exposure to lead in Brazil (Paoliello et al., 200527). Furthermore, lead exposure amongst pregnant women has been studied in French Guiana (Rimbaud et al., 201732), Malaysia (Hisham et al., 1998 ${ }^{16}$ ), Pakistan (Rahman et al., 2003 ${ }^{29}$ ), New Mexico (Bakhireva et al., 2013 ${ }^{6}$ ) and Mexico (Tellez-Rojo et al., 2004 ${ }^{37}$ ).

Lead poisoning in India, especially in human population of northern part of the country has also been monitored in the past. Blood lead concentration in pregnant women of urban slums of Lucknow (India) was estimated by Awasthi and coworkers (Awasthi et al., 19964). Maternal blood lead concentration was also found to affect pregnancy outcomes (Awasthi et al., 2002 ${ }^{5}$ ). Earlier studies from our laboratory have reported occupational toxicity of lead amongst painters, petrol pump operators and battery makers (Rana et al., 1991 ${ }^{30}$ ). Occupational exposure to lead in women bangle makers of India were also monitored

${ }^{*}$ Author for correspondence 
(Verma et al., 2007). Ecotoxicological studies on inorganic lead with special reference to northern India reported by Rana $(1999)^{31}$ included printing press workers, block makers and those working in brass-ware industry (Rana et al., 1999 ${ }^{31}$ ). All these studies have addressed the issue of lead exposure through observations on blood or urine lead concentration and $\delta$-aminolevulinic acid in urine samples of exposed subjects and found them to be reliable bio-markers of lead poisoning.

However, present communication appears to be the first report that describes lead exposure in expecting mothers of Meerut City in northern India. The main objective of present study was to assess the vulnerability of pregnant women to lead poisoning by estimating urinary lead $(\mathrm{PbU})$ and $\delta$-aminolevulinic acid (ALA-U) concentration. Further, an association between lead exposure and "whole body oxidative stress", if any, has also been examined by monitoring urinary concentration of thiobarbituric acid Reactive Substances (TBARS). Lead induced oxidative stress may contribute to disease conditions in expecting mothers and the fetus.

\section{Materials and Methods}

\subsection{Reagents/Chemicals}

Thiobarbituric acid, 1,1,3,3, tetramethoxypropane and aminolevulinic acid hydrochloride were procured from Sigma Chemical Company, St. Missouri (USA). Other reagents of highest purity were purchased from Hi-Media, Mumbai. Commercial kit for the determination of creatinine was supplied by Span Diagnostics (Surat, India).

\subsection{Subjects}

Eighty women reporting for routine check-up of pregnancy in different private hospitals/nursing homes in and around Meerut City (India) were selected for this study.

A priori inclusion criteria for this study were age (20-40 years), nutritional status (vegetarian and non-vegetarian) and social habits (smoking and alcohol intake). Those suffering from active diabetes, hypertension and active psychosis were excluded from the study. Non pregnant women meeting the same inclusion criteria were registered as controls. Selected women were informed of the purpose of study and procedures involved. They read or were read, a statement of informed consent, signed by them. Due approval of the Institutional Ethical Committee was also obtained to make these investigations.

\subsection{Collection of Urine Samples}

Thirty five pregnant women who passed the inclusion criteria were registered for present study performed during March to May, 2018. Urine samples (about $100 \mathrm{ml}$ ) from the selected subjects were collected during their routine check up in "sterilized lead free plastic bottles". They were preserved in the ice box and transported to the laboratory. All samples were stored at $-80^{\circ} \mathrm{C}$ till further analyses for following parameters.

\subsection{Specific Gravity}

Samples for analysis were brought to the room temperature. Specific gravity was determined using a urinometer (Atago Company Ltd, Japan). Samples showing specific gravity below 1.010 and higher than 1.030 were excluded from the study.

\subsection{Creatinine}

Concentration of creatinine in the selected samples was determined employing alkaline picrate spectrophotometric method as suggested by Toro and Ackerman (1972) ${ }^{41}$. Commercial kit obtained from Span Diagnostics (Surat), India was used for its measurement.

\subsection{Urine Lead Concentration}

All samples were analysed in duplicate employing atomic absorption spectrophotometry (Electronic Corporation, Hyderabad), using a hollow cathode lamp for lead. Absorption was recorded at $283.30 \mathrm{~nm}$. The analyses were performed in flame mode using acetylene compressed air $(3.5: 20.5 \mathrm{~L} / \mathrm{min})$ as described elsewhere (Verma et al., 2007) ${ }^{43}$.

\section{$2.7 \delta$-Aminolevulinic Acid}

Spectrophotometric method suggested by Tomokuni and Ogata $(1972)^{39}$ was used to determine $\delta$-aminolevulinic acid in the urine samples using Ehrlich reagent (Tomokuni et al., $1972^{39}$ ). Aminolevulinic acid hydrochloride (Sigma Chemical Company, USA) was used as the standard. Absorbance was recorded at $553 \mathrm{~nm}$ using a spectrophotometer (Systronics, India).

\subsection{Thiobarbituric Acid Reactive Substances (TBARS)}

TBARS in urine samples were measured using thiobarbituric acid method as suggested by Weitner (Weitner et al., 2016) ${ }^{45}$. Thiobarbituric acid and 1,1,3,3 tetra ethoxypropane (standard) were procured from Sigma Chemical Company, U.S.A. Absorbance was recorded at $532 \mathrm{~nm}$ using a spectrophotometer (Systronics, India).

\subsection{Statistical Analysis}

Students "t" test was applied to make comparisons amongst different groups. $\mathrm{p}$ values $<0.05$ were considered significant. 


\section{Results}

Lead concentration in the urine samples of pregnant women was found to be significantly higher than the non pregnant women. Further, women aged between 26-30 years excreted higher amount of lead $(52 \pm 0.01 \mu \mathrm{g} / \mathrm{dL})$ than those younger $(40 \pm 0.01 \mu \mathrm{g} / \mathrm{dL})$ or elder $(43 \pm 0.01 \mu / \mathrm{dL})$ women. Nonpregnant women between the ages of 20-25 years excreted significantly low concentration of lead (Table 1).

Another variable considered in this cohort was the influence of food habits on lead accumulation in pregnant women. The subjects of present study included both vegetarian and non-vegetarian women of selected age groups. Interestingly, lead concentration was found to be higher in the urine samples of non-vegetarian $(46 \pm 0.009 \mu \mathrm{g} / \mathrm{dL})$ than vegetarian women $(44 \pm 0.009 \mu \mathrm{g} / \mathrm{dL})$. Non-pregnant vegetarian as well as nonvegetarian women exhibited very low concentration of lead in their urine samples (Table 2).

Third parameter considered for present study was the concentration of delta aminolevulinic acid ( $\delta$-ALA) in the urine samples of pregnant women. In almost all cases, these results reciprocated with concentration of lead in urine samples (Table 1). Highest concentration $(2.60 \pm 0.55 \mathrm{mg} / \mathrm{l})$ was recorded in the women ranging from 26-30 years

Table 1. Biomarkers of lead poisoning in the pregnant women of Meerut City (India) in relation to their age

\begin{tabular}{|c|c|c|c|c|c|c|c|}
\hline Age Group & $\begin{array}{l}\text { Specific } \\
\text { Gravity }\end{array}$ & $\begin{array}{l}\text { Creatinine } \\
(\mathrm{mg} / \mathrm{l})\end{array}$ & $\begin{array}{c}\text { Pb-U } \\
(\mu \mathrm{g} / \mathrm{dL})\end{array}$ & $\begin{array}{l}\text { Pb-U cor. to } \\
\text { creatinine } \\
(\mu \mathrm{g} / \mathrm{g})\end{array}$ & $\begin{array}{c}\delta \text {-ALA U } \\
(\mathrm{mg} / \mathrm{L})\end{array}$ & $\begin{array}{c}\delta \text {-ALAU } \\
\text { cor. to creatinine } \\
(\mathrm{mg} / \mathrm{g})\end{array}$ & $\begin{array}{c}\text { TBARS } \\
(\mu \mathrm{M})\end{array}$ \\
\hline $\begin{array}{l}20-25 \text { years } \\
(\mathrm{n}=13)\end{array}$ & $1.031 \pm 0.011^{\star}$ & $185 \pm 0.31^{*}$ & $40 \pm 0.01$ & $21.62 \pm 5.64^{*}$ & $1.86 \pm 0.48^{*}$ & $10.05 \pm 1.02^{\star}$ & $5.58 \pm 0.77^{\star}$ \\
\hline $\begin{array}{l}26-30 \text { years } \\
(n=12)\end{array}$ & $1.017 \pm 0.001$ & $167 \pm 0.22^{*}$ & $52 \pm 0.01^{*}$ & $31.13 \pm 5.14^{*}$ & $2.60 \pm 0.55^{*}$ & $15.56 \pm 1.03^{*}$ & $4.61 \pm 0.66$ \\
\hline $\begin{array}{l}31-40 \text { years } \\
(\mathrm{n}=5)\end{array}$ & $1.018 \pm 0.003$ & $182 \pm 0.23^{*}$ & $43 \pm 0.01^{\star}$ & $23.62 \pm 6.36$ & $1.90 \pm 1.06^{*}$ & $10.53 \pm 3.64^{*}$ & $3.93 \pm 0.35$ \\
\hline $\begin{array}{l}\text { Control } \\
\text { Non-pregnant } \\
\text { women } \\
(\mathrm{n}=5)\end{array}$ & $1.016 \pm 0.002$ & $121 \pm 0.17$ & $33 \pm 0.01$ & $27.27 \pm 2.20$ & $0.42 \pm 0.18$ & $3.47 \pm 1.86$ & $4.30 \pm 0.05$ \\
\hline
\end{tabular}

Results are expressed as mean \pm SE. (no. of subjects are shown in parentheses)

${ }^{*}$ Results are significantly different from non-pregnant controls $(\mathrm{p}<0.05)$

NS = Denotes non-significant results.

Table 2 Biomarkers of Lead poisoning in pregnant women of Meerut City (India) in relation to their food habits

\begin{tabular}{|l|c|c|c|c|c|c|c|}
\hline Food habit & $\begin{array}{c}\text { Specific } \\
\text { gravity } \\
(\mathrm{mg} / \mathrm{l})\end{array}$ & $\begin{array}{c}\text { Creatinine } \\
(\mu \mathrm{g} / \mathrm{dL})\end{array}$ & $\begin{array}{c}\text { Pb-U cor. to } \\
\text { creatinine } \\
(\mu \mathrm{g} / \mathrm{g})\end{array}$ & $\begin{array}{c}\delta \text {-ALA U } \\
(\mathrm{mg} / \mathrm{L})\end{array}$ & $\begin{array}{c}\delta \text {-ALAU } \\
\text { cor. to creatinine } \\
(\mathrm{mg} / \mathrm{g})\end{array}$ & $\begin{array}{c}\text { TBARS } \\
(\mu \mathrm{M})\end{array}$ \\
\hline $\begin{array}{l}\text { Pregnant+ Vegetarian } \\
(\mathrm{n}=12)\end{array}$ & $1.015 \pm 0.001 \mathrm{NS}$ & $126 \pm 0.16^{*}$ & $44 \pm 0.009^{*}$ & $34.92 \pm 6.6 \mathrm{NS}$ & $1.31 \pm 0.64^{*}$ & $10.39 \pm 1.3^{*}$ & $4.49 \pm 0.7^{*}$ \\
\hline $\begin{array}{l}\text { Non-pregnant+ } \\
\text { Vegetarian } \\
(\mathrm{n}=5)\end{array}$ & $1.016 \pm 0.001 \mathrm{NS}$ & $140 \pm 0.46$ & $32 \pm 0.006 \mathrm{NS}$ & $22.85 \pm 3.8$ & $0.51 \pm 0.016 \mathrm{NS}$ & $3.57 \pm 2.6 \mathrm{NS}$ & $4.35 \pm 0.0007 \mathrm{NS}$ \\
\hline $\begin{array}{l}\text { Pregnant+ } \\
\text { Non-vegetarian } \\
(\mathrm{n}=13)\end{array}$ & $1.021 \pm 0.001^{*}$ & $214 \pm 0.22^{*}$ & $46 \pm 0.009^{*}$ & $21.49 \pm 5.3^{*}$ & $2.11 \pm 0.35^{*}$ & $9.85 \pm 0.9^{*}$ & $5.56 \pm 0.6^{*}$ \\
\hline $\begin{array}{l}\text { Non-pregnant+ } \\
\text { non-vegetarian } \\
(\mathrm{n}=5)\end{array}$ & $1.017 \pm 0.003$ & $108 \pm 0.05$ & $34 \pm 0.021$ & $31.48 \pm 3.1$ & $0.4 \pm 0.26$ & $3.70 \pm 2.6$ & $4.27 \pm 0.007$ \\
\hline
\end{tabular}

Results are expressed as mean \pm SE. (no. of subjects are shown in parentheses)

${ }^{\star}$ Results are significantly different from non-pregnant controls $(\mathrm{p}<0.05)$.

NS= Denotes non-significant results. 
of age. Amongst vegetarian and non-vegetarian women, concentration of $\delta$-ALA-U was higher in the urine samples of vegetarian subjects. These results were also in agreement with lead concentration in urine samples (Table 2).

None of the selected pregnant/non pregnant women reportedly smoked or consumed alcohol.

TBARS in the urine samples were estimated as a noninvasive marker of whole body oxidative stress. Present observations demonstrated that pregnant women were under oxidative stress. Although all pregnant women of all age groups and irrespective of food habits exhibited significantly higher values for TBARS than non-pregnant women, women in the age group of 20-25 years and those consuming non-vegetarian diet showed comparatively higher values for these chromogens (Tables 1 and 2).

\section{Discussion}

Concept of Biological Monitoring (BM) perhaps started with the estimation of lead in blood and urine samples of human subjects occupationally exposed to lead. It was in 1972, Zielhuis $^{48}$ discussed the issue in an international conference organized in Amsterdam, Netherlands (Zielhuis, 1972) ${ }^{48}$. A biological quality guide for inorganic lead, for the first time, was published by Zielhuis (Zielhuis, 1974) ${ }^{47}$. American Conference of Governmental and Industrial Hygienists $(\mathrm{ACGIH})^{1}$ also recommended the measurement of blood/ urinary lead concentration as a biomarker to determine the occupational exposure to lead (ACGIH, 2012) ${ }^{1}$. Blood or urinary concentration of lead in healthy (unexposed) human subjects of different countries has been found to vary, however, low concentration of blood lead $(<10 \mu \mathrm{g} / \mathrm{dL})$ represent typical environmental exposures in many developing countries (Tong et al., 2000 ${ }^{40}$. Earlier reports from our laboratory have demonstrated higher lead concentration in urine $(\mathrm{Pb}-\mathrm{U})$ in men $(7 \mu \mathrm{g} / \mathrm{dL})$ than women $(4 \mu \mathrm{g} / \mathrm{dL})$ (Verma et al., 2007) ${ }^{43}$. Other reports confirm that men generally retain higher concentration of blood/urine lead than women (Nriagu et al., $2006^{25}$, Lofstedt et al., $1999^{20}$, Leroyer et al., $2001^{19}$ ).

In addition to gender differences, issues related to environmental lead exposure and pregnancy outcome have also been addressed in several countries (EPA, 1972) ${ }^{11}$. Pregnancy is an important and unique period of women's life in which there is high sensitivity to toxic agents. Increased blood lead concentration, either through endogenous (bone saved) or ambient environmental lead exposure, may affect health of expecting mothers and could be extremely harmful to the fetus.

Present study found higher concentration of $\mathrm{Pb}-\mathrm{U}$ $(\geq 40 \mu \mathrm{g} / \mathrm{dL}$ ) in pregnant women. It was comparatively higher than the pregnant women of several other countries. In Japan, blood lead level has been found to be $3.7 \mu \mathrm{g} / \mathrm{dL}$ (Saito et al.,
2006) $)^{34}$. However, it was found to be higher $(7.71 \mu \mathrm{g} / \mathrm{dL})$ in the pregnant women of Malaysia (Hisham et al., 1998) ${ }^{16}$. In another study made in Pakistan, mean blood lead concentration in pregnant women was $9.91 \mu \mathrm{g} / \mathrm{dL}$ (Rahman et al., 2003) ${ }^{29}$. Changes in blood lead level in pregnant women of Mexico City were monitored by Rothenberg (Rothenberg et al., 1994) ${ }^{33}$. Blood lead level averaged $7.0 \mu \mathrm{g} / \mathrm{dL}$ with a range of 1.0 to 35.5 $\mu \mathrm{g} / \mathrm{dL}$ throughout pregnancy. Blood lead concentration in the pregnant women of French Guiana averaged $32 \mu \mathrm{g} / \mathrm{dL}$ (Rimbaud et al., 2017) ${ }^{32}$. These differences could be attributed to prevalence of lead in ambient environment, food or work environment.

In addition, we studied the effect of age on the retention/ accumulation of lead in pregnant women. Younger women showed lower $\mathrm{Pb}-\mathrm{U}$ concentration then the older women. In a few reports, maternal blood lead concentration has been related with the ageing process. A study made in the pregnant women of Durham County (USA) also showed that younger women had reduced risk of lead poisoning than older women (Miranda et al., 2010) ${ }^{21}$. It is hypothesized that pregnant women serve as reservoirs of lead stores. The accumulated lead is remobilized to the blood stream through natural ageing process. Further, rates of mobilization are likely to be accelerated by the physiological stress and disturbances in calcium homeostasis during pregnancy (CDC, 2010)

No attempt to screen lead poisoning in pregnant women/ lactating mothers/children through the estimation of $\delta$-aminolevulinic acid Dehydratase activity (ALAD) in the blood or $\delta$-aminolevulinic acid in the Urine (ALAU) has seemingly been made earlier in India. We assume that these observations possess immense clinical significance. Lead inhibits enzymes associated with heme synthesis (Chisolm, $1971^{9}$, De Bruin, $1971^{10}$ ). The inhibition of $\delta$-aminolevulinic acid Dehydratase (ALA D) and heme synthetase by lead has been reported earlier also (Granick et al., 1973) ${ }^{15}$. Consequently $\delta$-aminolevulinic acid (ALA) accumulates in serum and subsequently excreted in urine. Our results on ALAU show higher concentration in middle age women (26-30 years) in comparison to younger (20-25 years) or older (31-40 years) pregnant women. These results support the hypothesis that younger women have reduced risk of lead poisoning as suggested by Miranda (Miranda et al., 2010) ${ }^{21}$.

Further, we noticed that vegetarian women were at higher risk of lead poisoning than non-vegetarian pregnant women. An earlier report from our laboratory supplements these results (Verma et al., 2007) ${ }^{43}$. A recent study made in Mexico by La-Llave-Leon correlated blood lead levels with ALAD activity in pregnant women and registered a negative correlation between these two parameters (La-Llav-Leon et al., 2017) ${ }^{18}$.

We made an attempt to demonstrate a correlation between $\mathrm{PbU}$ levels and whole body oxidative stress in pregnant women. High PbU levels reciprocated with high TBARS values 
in expecting mothers. It is suggested that TBARS in urine could be a suitable marker of "whole body oxidative stress". An association between $\mathrm{PbB}$ levels and oxidative stress in pregnant women of Lucknow, (India) has been suggested (Tiwari et al., $2012)^{38}$. They hypothesized that high levels of blood lead (PbB), Zinc Protoporphyrin (ZPP), Oxidized Glutathione (GSSG) and Lipid Peroxide (LPO) contribute to inhibition of $\delta$-ALAD. Our observations on ALAU also find support from this study.

Two agencies viz. Centre for Disease control (CDC) ${ }^{8}$ and American Conference of Governmental and Industrial Hygienists (ACGIH) ${ }^{1}$ had set guidelines on lead poisoning. ACGIH has set a Biological Exposure Index (BEI) for blood lead at $30 \mu \mathrm{g} / \mathrm{dL}$ (ACGIH, 2012 ${ }^{1}$ ). In 2015, National Institute of Occupational Safety and Health (NIOSH) designated 5 $\mu \mathrm{g} / \mathrm{dL}$ as a reference blood level for adults. The National Toxicology Program (NTP) concludes that there is sufficient evidence for adverse health effects in children and adults at $\mathrm{PbB}<5 \mu \mathrm{g} / \mathrm{dL}$ (NTP, 2012) ${ }^{26}$. Present investigations show that non pregnant Indian women in general, carry much higher levels of blood lead than those of other countries. To note, whatever may be the factors for enhanced blood levels in Indian women, physiological factors are expected to influence lead accumulation in pregnant women. These variables include accelerated absorption of dietary lead, or decreased elimination of lead from the body and release of stored lead from the bones during pregnancy. Processes that mobilize calcium from the bones during pregnancy may also mobilize lead from the bones (Fullmer, 1991) ${ }^{12}$. Lead may also be released from the bone during times of high calcium stress generally observed in pregnant women taking calcium deficient diets (Silbergeld, $1991)^{36}$. Most of the pregnant women (75\%) in India are calcium deficient and malnourished. Further, consumption of lead contaminated food may enhance $\mathrm{PbB}$ levels during pregnancy.

In conclusion, there is a critical need to identify the sources of environmental lead exposure especially in pregnant women of India. Lead diffuses from mother's blood-stream to the fetus through placenta and accumulates in fetal organs. Since biological half life of lead in bones is 5-20 years (Nilsson et al., 1991) ${ }^{23}$, pregnant women and their growing fetuses remain at the risk of lead poisoning for coming decades.

\section{Conflict of Interest}

The authors have no conflict of interest.

\section{Acknowledgement}

The authors thank all the women subjects who participated in this study. Technical support from Ms. Kavita Rana and Mrs. Varsha Sharma is also gratefully acknowledged.

\section{References}

1. ACGIH (American Conference of Governmental and Industrial Hygienists). Threshold limit values for chemical substances and physical agents and biological exposure indices: Cincinnanti, $\mathrm{OH} ; 2012$.

2. Amitai Y, Katz D, Lifshitz M, Gofin R, Tepferberg M, Almog S. Prenatal lead exposure in Israel: An international comparison. The Israel Medical Association Journal. 1999; 1:250-3.

3. ASTDR (Agency for Toxic Substances and Disease Registry). Toxicological profile for lead. Atlanta (GA): ASTDR; 2007.

4. Awasthi S, Awasthi R, Pande VK, Srivastav RC, Frumkin H. Blood lead in pregnant women in the urban slums of Lucknow, India. Occupational and Environmental Medicine. 1996; 53(12): 836-40. PMid: 9004930 PMCid: PMC1128618. https://doi. org/10.1136/oem.53.12.836

5. Awasthi S, Awasthi R, Srivastav RC. Maternal blood lead level and outcomes of pregnancy in Lucknow, North India. Indian Pediatrics. 2002; 39: 855-60.

6. Bakhireva LN, Rowland AS, Young BN, Cano S, Phelan ST, Artyushkova K, Rayburn WF, Lewis J. Sources of potential lead exposure among pregnant women in New Mexico. Maternal and Child Health Journal. 2013; 17(1):172-9. PMid: 22362260 PMCid: PMC3564678. https://doi.org/10.1007/s10995-0120963-5

7. Barry P I. Distribution and storage of lead in human tissues. Nriagu JO, ed. The biogeochemistry of Lead in the Environment. Biological Effects. Elsevier Amsterdam; 1978. 97-150.

8. CDC (Centers for Disease Control). Guidelines for the identification and management of lead exposure in pregnant and lactating women. Atlanta, GA: US Department of Health and Human Services, CDC; 2010.

9. Chisolm JJ Jr. Lead poisoning. Scientific American. 1971; 224(2):15-23. PMid: 5101815. https://doi.org/10.1038/scientificamerican0271-15

10. De Bruin A. Certain biological effects of lead upon the animal organism. Archives of Environmental and Occupational Health. 1971; 23(4):249-64. PMid: 4939125. https://doi.org/10.1080/000 39896.1971.10665996

11. EPA (The Environmental Protection Agency). EPA's position on health effects of air borne lead. Washington. 1972.

12. Fullmer CS. Intestinal calcium and lead absorption: Effects of dietary lead and calcium. Environmental Research. 1991; 54(2):159-69. https://doi.org/10.1016/S0013-9351(05)80098-2

13. Gaur S, Singh N, Saxena S. Status of lead present in ground drinking water samples of Uttarakhand (Garhwal Region) in India. Asian Journal of Biomedical and Pharmaceutical Sciences. 2011; 1(1):32-8.

14. Goyer RA. Results of lead research: Prenatal exposure and neurological consequences. Environmental Health Perspectives. 1996; 104(10):1050-4. PMid: 8930545 PMCid: PMC1469478. https:// doi.org/10.1289/ehp.961041050

15. Granick JL, Sassa S, Granick S, Levera R, Kappas A. Studies in lead poisoning. II Correlation between the ratio of activated to inactivated-aminolevulinic acid dehydratase of whole blood 
and the blood lead levels. Biochemical Medicine. 1973; 8:149-59. https://doi.org/10.1016/0006-2944(73)90018-5

16. Hisham HJ, Chuah SY, Syarif HL, Nik Nasri I, Fairulnizam MN. Blood lead levels of pregnant women from the Klang valley. Medical Journal of Malaysia. 1998; 53(1):76-81.

17. Kulshreshtha A, Soni RK, Shinde CP. Quantitative estimation of heavy metals in ground water in Meerut Region in Uttar Pradesh. IOSR Journal of Applied Chemistry. 2015; 8(8):46-9.

18. La-Llav-Leon O, Mendez-Hernandez EM, CastellanosJuarez FX, et al. Association between blood lead levels and Delta-aminolevulinic acid dehydratase in pregnant women. International Journal of Environmental Research and Public Health. 2017; 14(4):432. PMid: 28420209 PMCid: PMC5409633. https://doi.org/10.3390/ijerph14040432

19. Leroyer A, Hemon D, Nisse C, Bazerques J, Salomez JL, Haguenoer JM. Environmental exposure to lead in a population of adults living in northern France: Lead burden levels and their determinants. Science of the Total Environment. 2001; 267(1-3):87-99. https://doi.org/10.1016/S0048-9697(00)00762-2

20. Lofstedt H, Seldon A, Storeus L, Bodin L. Blood lead in Swedish police officers. American Journal of Industrial Medicine. 1999; 35:519-22. https://doi.org/10.1002/(SICI)10970274(199905)35:5<519::AID-AJIM9>3.0.CO;2-N

21. Miranda ML, Edwards SE, Swamy GK, Paul CJ, Neelon B. Blood lead levels among pregnant women: Historical versus contemporaneous exposures. International Journal of Environmental Research and Public Health. 2010; 7(4):1508-19. PMid: 20617043 PMCid: PMC2872339. https://doi.org/10.3390/ijerph7041508

22. National Ambient Air Quality Standards, Central Pollution Control Board Notification in the Gazette of India, Extraordinary, New Delhi; 2009.

23. Nilsson U, Attewell R, Christoffersson JO, Schultz A, Ahlgren L, Skerfving S, Mattsson S. Kinetics of lead in bone and blood after end of occupational exposure. American Journal of Pharmacology and Toxicology. 1991; 68(6):477-84. PMid: 1891443. https://doi.org/10.1111/j.1600-0773.1991.tb01273.x

24. NRCLPI (National Referral Centre for Lead Poisoning in India). Project to combat lead poisoning. Hindu. 2002.

25. Nriagu J, Burt B, Linder A, Ismail A, Sohn W. Lead levels in blood and saliva in a low-income population of Detroit, Michigan. International Journal of Hygiene and Environmental Health. 2006; 209:109-21. PMid: 16443391 PMCid: PMC1819402. https://doi.org/10.1016/j.ijheh.2005.11.005

26. NTP (National Toxicology Program). Monograph on Health Effects of Low-Level Lead Evaluation [prepublication copy]. Research Triangle Park, NC: National Toxicology Program, U.S. Department of Health and Human Services. 2012.

27. Paoliello MM, De Capitani EM. Environmental contamination and human exposure to lead in Brazil. Reviews of Environmental Contamination and Toxicology. 2005; 184:59-96. PMid: 15790173. https://doi.org/10.1007/0-387-27565-7_2

28. Patterson C, Ericson J, Manea-Krichten M, Shirahata $H$. Natural skeletal levels of lead in Homo sapiens sapiens uncontaminated by technological lead. Science of the Total
Environment. 1991; 107(1991):205-36. https://doi.org/10.1016/ 0048-9697(91)90260-L

29. Rahman A, Hakeem A. Blood lead levels during pregnancy and pregnancy outcome in Karachi women. Journal of the Pakistan Medical Association. 2003; 53(11):529-33.

30. Rana SVS, Rastogi S, Verma R. Biological monitoring of occupational exposure to lead in Indian painters, petrol pump workers, battery makers and pottery makers. Journal of Ecotoxicology and Environmental Monitoring. 1991; 1(4):302-6.

31. Rana SVS. Ecotoxicological studies on inorganic lead - A case study of Uttar Pradesh. «Environment and Health». Agrawal VP and Rana SVS, Ed. Society of Biosciences. 1999. p. 147-54.

32. Rimbaud D, Restrepo M, Louison A, Boukhari R, Ardillon V, Carles G, Lambert V, Jolivet A. Blood lead levels and risk factors for lead exposure among pregnant women in Western French Guiana: The role of manioc consumption. Journal of Toxicology and Environmental Health, Part A. 2017; 80(6):382-93. PMid: 28644767. https://doi.org/10.1080/15287394.2017.1331490

33. Rothenberg SJ, Karchmer S, Schnaas L, Perroni E, Zea F, Fernandez Alba J. Changes in serial blood lead levels during pregnancy. Environmental Health Perspectives. 1994; 102(10):876-80. PMid: 9644197 PMCid: PMC1567359. https:// doi.org/10.1289/ehp.94102876

34. Saito H, Mori I, Ogawa Y, Hirata M. Relationship between blood lead level and work related factors using the NIIH questionnaire system. Industrial Health. 2006; 44:619-28. PMid: 17085924. https://doi.org/10.2486/indhealth.44.619

35. Sallmen M, Anttila A, Lindbohm ML, Kyyronen P, Taskinen $\mathrm{H}$, Hemminki K. Time to pregnancy among women occupationally exposed to lead. Occupational and Environmental Medicine. 1995; 37(8):931-4. PMid: 8520955. https://doi. org/10.1097/00043764-199508000-00007

36. Silbergeld EK. Lead in bone: Implications for toxicology during pregnancy and lactation. Environmental Health Perspectives. 1991; 91:63-70. PMid: 2040252 PMCid: PMC1519355. https://doi.org/10.1289/ehp.919163

37. Tellez-Rojo MM, Hernandez-Avila M, Lamadrid-Figueroa $\mathrm{H}$, Smith D, et al. Impact of bone lead and bone reabsorption on plasma and whole blood lead levels during pregnancy. American Journal of Epidemiology. 2004; 160:668-78. PMid: 15383411. https://doi.org/10.1093/aje/kwh271

38. Tiwari AK, Mahdi AA, Zahra F, Sharma S, Negi MP. Evaluation of low blood lead levels and its association with oxidative stress in pregnant anemic women: A comparative prospective study. Indian Journal of Clinical Biochemistry. 2012; 27(3):246-52. PMid: 26405382 PMCid: PMC4577501. https://doi.org/10.1007/ s12291-012-0202-2

39. Tomokuni K, Ogata M. Simple method for determination of urinary delta-aminolevulinic acid as an index of exposure. Clinical Chemistry. 1972; 18:1534-36. PMid: 4639865. https://doi.org/10.1093/clinchem/18.12.1534

40. Tong S, Von Schirnding YE, Prapamontol T. Environmental lead exposure: A public health problem of global dimensions. Bulletin of the World Health Organization. 2000; 78:1068-77. 
41. Toro G, Ackermann P. Practical clinical chemistry, first ed. Boston: Little, Brown and Company; 1972.

42. Tsuchiya K. Lead. Ch. 14. Handbook on the Toxicology of Metals. Vol. II: Specific Metals, 2nd ed, Friberg L, et al., Ed. Elsevier, New York. 1986. p. 298.

43. Verma Y, Gautam RK, Rana SVS. Biological monitoring of exposure to inorganic lead with special reference to women - A case study of Indian bangle makers. Toxicology International. 2007; 14(2):123-31.

44. www.vikasecotech.com. Vikas Ecotech Ltd, 2016.

45. Weitner T, Inic S, Jablan J, Gabricevic M. Spectrophotometric determination of malondialdehyde in urine suitable for epidemiological studies. Croatica Chemica Acta. 2016; 89(1):133-9. https://doi.org/10.5562/cca2902
46. Wu T, Buck GM, Mendola P. Blood lead levels and sexual maturation in U.S. girls: Third National Health and Nutrition Examination Survey, 1988-1994. Environmental Health Perspectives. 2003; 111:737-41. PMid: 12727603 PMCid: PMC1241484. https://doi.org/10.1289/ehp.6008

47. Zielhuis RL. Biological quality guide for inorganic lead. Int Arch Arbeitsmed. 1974; 32:103-27. PMid: 4813690. https://doi. org/10.1007/BF00539100

48. Zielhuis RL. Lead absorption and public health. An appraisal of hazards. Int Symposium on Environmental Health Aspects of Lead. Amsterdam: CEC. EPA. Amst; 1972. 